\title{
The Effects of Mathematics
}

\section{Anxiety on Matriculation Students as Related to Motivation and Achievement}

\author{
Effandi Zakaria and Norazah Mohd Nordin \\ Universiti Kebangsaan Malaysia, Selangor, MALAYSLA
}

The study investigated the effects of mathematics anxiety on matriculation students as related to motivation and achievement. Subjects included 88 students who were at the end of their second semester of study. Anxiety and motivation were measured using the Fennema-Sherman Math Anxiety Scale (MAS) and Effectance Motivation Scale (EMS) respectively. The instrument used to measure achievement was the Mathematics Achievement Test (MAT). The ANOVA results showed that the mean achievement scores and motivation scores of low, moderate and high anxiety groups were significantly different. Findings also revealed a low $(r=-0.32)$ but significant $(p<0.05)$ negative correlation between mathematics anxiety and achievement and also a strong $(\mathrm{r}=-0.72)$ significant $(\mathrm{p}<0.05)$ negative correlation between mathematics anxiety and motivation. The study also revealed a significant low positive correlation $(\mathrm{r}=0.31)$ between motivation and achievement

Keywords: Mathematics Anxiety, Motivation, Achievement, Matriculation Students

\section{INTRODUCTION}

Mathematics anxiety is prevalent among the college students population (Betz 1978). Studies by Rahmah (1999), Ahmad Sukri et al. (1996) and Jasmani Bidin et al. (2005) found that a majority of Malaysian students have moderate level of mathematics anxiety. Lazarus (1974) believed that the roots of mathematics anxiety are in the elementary and secondary grades. In a similar vein, Jackson and Leffingwell (1999) have linked mathematics anxiety to prior experience with formal instruction in mathematics at the elementary and secondary level. They found that $16 \%$ of the students surveyed had their first negative experience with mathematics instruction as early as grades 3 and 4 . This is cause for concern, considering that matriculation students may bring these negative feelings to their university studies.

Correspondence to: Effandi Zakaria, Senior Lecturer-Dr Mathematics Education, Faculty of Education, Universiti Kebangsaan Malaysia, 43600 Bangi, Selangor, Malaysia. E-mail:effandi@ukm.my
A review of current research suggests that low achievers in mathematics frequently accompany the incidence of mathematics anxiety. Ma (1999) found that the relationship between mathematics anxiety and mathematics achievement is significant. It was also found that once maths anxiety takes shape, its relationship with maths achievement is consistent across grade levels. Satake and Amato (1995) and Hardfield et al. (1992) also reported similar findings. A high level of anxiety is associated with a lower level of achievement (Quilter \& Harper, 1988). Other than achievement, Tapia (2004) reported that students having little or no math anxiety scored significantly higher in motivation than students with some or high math anxiety, and students with some math anxiety scored significantly higher than students with high math anxiety. Bretscher et al. (1989) found that students who were involved in learning because wanted to be, scored significantly higher than their counterparts. They further contended that effectance motivation was a predictor of mathematics achievement. This influence is understandable since students with high motivation usually enjoy doing mathematics, stick at problems until 
they are solved and become absorbed in their mathematical problem solving activities.

Levine (1995) described math anxiety as involving feelings of anxiety and tension that interfere with doing mathematical operations. Math anxiety existed around a set of circumstances in which students suffered from fears that were based upon years of painful experiences with mathematics (Miller \& Mitchell, 1994). Maths anxiety has been defined as the feeling of tension, helplessness, mental disorganisation and dread one has when required to manipulate numbers and shapes and the solving of mathematical problems (Ashcraft \& Faust, 1994). Fennema and Sherman (1976) described math anxiety as involving strong feelings of fear and apprehension when faced with the possibility of dealing with a math problem.

Norwood (1994) emphasized that math anxiety did not appear to have single cause, but was, in fact, the result of many different factors such as truancy, poor self image, poor coping skills, teacher attitude and emphasis on learning maths through drill without understanding. However, Greenwood (1984) further stated that the principal cause of mathematics anxiety has been in teaching methodologies. He said math classes did not encouraged reasoning and understanding. The problems with math anxiety would not go away until teachers applied the problem solving process to the teaching of arithmetics and mathematics (Geenwood, 1984). Butterworth (1999) believes that a lack of understanding is the cause of anxiety and avoidance and that understanding based learning is more effective than drill and practice. A lack of confidence when working in mathematical situations is described by Stuart (2000) as the cause of maths anxiety. Highly maths anxious individuals will be less fluent in computation, less knowledgeable about mathematics, and less likely to have discovered special strategies and relationships within the mathematics domain (Ashcraft \& Faust, 1994). In order to reduce mathematics anxiety and increase achievement, Miller and Mitchell (1994) suggested that teacher should create a positive learning environment, free from tension and possible causes of embarassment or humiliation.

\section{RATIONALE OF STUDY}

One of the aims of matriculation education was to further develop students' knowledge, competency and interest in the subject area. In a study by Rokiah and Mazlina (1998) on first year engineering students from matriculation, it was found that students had a negative attitudes towards mathematics. From my own teaching experience, some students do well during mathematics lesson and assignment yet fail to perform well in examination. Although there are many diverse reasons for the poor performance in mathematics, one prevalent variable worth considering is mathematics anxiety. Since little research has been done locally in the area of mathematics anxiety of matriculation students, this study was undertaken to add to that body of knowledge.

\section{PURPOSE}

The purpose of this study was to investigate whether there was a statistical difference between matriculation students' motivation and achievement when they were classified according to the math anxiety levels. Further, this study also sought to find out whether there was a significant correlation between (a) mathematics anxiety and motivation, and (b) mathematics anxiety and achievement.

\section{METHODOLOGY}

The study involved 88 students (73 females and 15 males). The participants were overwelmingly female, therefore no attempt was made to differentiate results by gender. Students were informed that their participations in the study were completely voluntary and would not influence their grade in the course. Three instruments were used to obtain the data: the Mathematics Anxiety Scale (MAS), Effectance Motivation Scale (EMS) and the Mathematics Achievement Test (MAT). The MAS and the EMS is a 12-item instrument, six worded positively and six worded negatively (Fennema \& Sherman, 1976). The instrument uses a Likert scale with a range of strongly agree to strongly disagree. A total score is calculated by assigning a value of 1 (strongly disagree) to 5 (strongly agree) to each item and then adding the values. Possible scores range from 12 to 60 . It is important to know that a low score on the MAS indicates a high level of mathematics anxiety, therefore the sign was reversed so that high scores would indicate high mathematics anxiety. According to Fennema and Sherman (1976), both the Math Anxiety Scale and Effectance Motivation Scale have a split-half reliability of 0.89 and 0.87 respectively. The instrument used for measuring mathematics achievement was the Mathematics Achievement Test (MAT). The MAT is a 12 questions open ended test with a 2 hour time limit.

Matriculation students' math anxiety scores were used to assign them into three groups: low math anxiety group, moderate anxiety group and high math anxiety group. The classification of the students was made by using the percentiles of the anxiety scores. Students whose scores fell between $33 \%$ and $67 \%$ were considered the moderate group. Low and high anxiety groups consisted of the students whose scores were in the lower $33 \%$ and in the upper $33 \%$ of the distribution, respectively. One way ANOVA tests and Tukey's HSD (Honestly Significant Difference) tests were used to 
compare the mean EMS and MAT scores of the different math anxiety groups. The Pearson product correlation coefficients of the participants' EMS and MAT scores and math anxiety scores were calculated to explain the possible relationships between these variables.

\section{RESULTS}

The number of students in each anxiety group and the mean scores for dependent variables are reported in Table 1.

The ANOVA results as shown in Table 2, revealed that the mean achievement scores of low, moderate and high anxiety groups were significantly different, $\mathrm{F}(2,85)=3.75, \mathrm{p}<0.05$. According to the Tukey's HSD tests, the mean differences in achievement test between the low and high anxiety groups were found to be statistically significant. On the other hand, the comparison of the mean scores of low and moderate anxiety and between moderate and high anxiety groups provided insignificant results at 0.05 significance level.

For motivation, as shown in Table 3, ANOVA results show that the mean motivation scores of low, moderate and high anxiety groups were also significantly different, $\mathrm{F}(2,85)=24.97, \mathrm{p}<0.05$. According to the Tukey's HSD tests, the mean differences between the low and moderate anxiety groups, between the low and high anxiety groups and between moderate and high anxiety groups were found to be statistically significant. Findings also revealed a low $(\mathrm{r}=-0.32)$ but significant $(\mathrm{p}$ $<0.05)$ negative correlation between mathematics anxiety and achievement and also a strong $(\mathrm{r}=-0.72)$ significant $(\mathrm{p}<0.05)$ negative correlation between mathematics anxiety and motivation. The study also revealed a significant low positive correlation $(\mathrm{r}=0.31)$ between motivation and achievement.

\section{DISCUSSION}

The results indicated that matriculation students with high mathematics anxiety scored significantly lower in achievement. Numerous authors have suggested that higher achieving students are more apt to be less anxious (Betz, 1978; Hembree, 1990; Skiba, 1990). The data analysis also indicated that the effect of math anxiety on motivation was significant. Students with low math anxiety scoring significantly higher than students with moderate or high math anxiety and students with moderate anxiety scoring significantly higher than students with high math anxiety. These results concurred with the findings of Tapia (2004). The results also indicated that there was a relationship between mathematics anxiety and achievement. This indicates that as math anxiety scores increase, achievement scores decrease. This finding is consistent with the studies of Betz (1978), Ma (1999) and Woodard (2004), which revealed a negative relationship between these two variables. Although the magnitude of the correlations calculated is not very high, teacher should be aware of the needs and the capabilities of the students with different mathematics anxiety levels when designing teaching strategies for them. There could be other variables that have significantly influenced the students achievement that were not identified and explored in this study. A strong correlation between mathematics anxiety and motivation is not surprising. This would indicate that students with high anxiety will be less

Table 1: Comparisons of Mean by Level of Math Anxiety

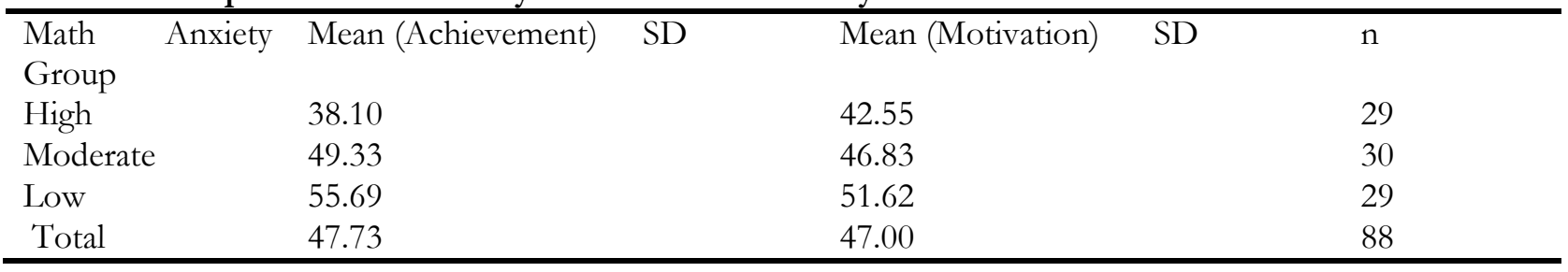

Table 2: Results of the ANOVA for Mathematics Achievement Scores

\begin{tabular}{lllll}
\hline Source of Variation & Degree of Freedom & Mean Squares & F & Sig \\
\hline Between Groups & 2 & 2300.95 & 3.75 & 0.028 \\
Within Groups & 85 & 614.04 & & \\
\hline
\end{tabular}

Table 3: Results of the ANOVA for Motivation Scores

\begin{tabular}{lllll}
\hline Source of Variation & Degree of Freedom & Mean Squares & F & Sig \\
\hline Between Groups & 2 & 596.92 & 24.97 & 0.000 \\
Within Groups & 85 & 23.91 & & \\
\hline
\end{tabular}


motivated in doing things related to mathematics. The significant low positive correlation between motivation and achievement showed that all the variables were interrelated with one another. The results of this study provide evidence that mathematics anxiety has an important effect in mathematics education that cannot be ignored. Therefore, teacher should be thinking on how to reduce students' anxieties by finding a better ways to teach mathematics.

\section{IMPLICATIONS}

Teachers need to be aware of the effects of anxiety on students' achievement and motivation. They should make an effort to lessen anxiety on these students. Teachers should develop teaching strategies that help highly anxious students. Woodard (2004) suggested the following techniques: (a) Create an environment in which students do not feel threatened and allow them to relax. (b) Use cooperative grouping. It helps students to understand that others have the same problems as they do. (c) Teach at a slow pace. It can help students better comprehend the material being taught. (d) Provide extra tuition sessions so that they are not left behind academically. With all these efforts it can be a positive force in reducing mathematics anxiety. Mathematics teacher should show their students a sincere, caring attitude to help them overcome mathematics anxiety.

\section{REFERENCES}

Ahmad Shukri Yahaya, Hafsah Abdul Majid \& Muriati Mukhtar (1996). Kegelisahan matematik di kalangan pelajar kejuruteraaan, Kampus Cawangan Perak. Prosiding Simposium Kebangsaan Sains Matematik ke VII. [Mathematics anxiety among engineering university students, Perak Branch Campus. Proceedings of the National Mathematical Science Simposium VII]. Perak:USM.

Ashcraft, M. \& Faust, M. (1994). Mathematics anxiety and mental arithmetic performance: An exploratory investigation. Cognition and Emotion, 8(2), 97-125.

Betz, N. (1978). Prevalence, distribution, and correlates of math anxiety in college students. Journal of Counseling Psychology, 25(5), 441-48.

Bretscher, A.S., Dwinell, P.L., Hey, N.S \& Higbee, J.L. (1989). Success or failure: Variables affecting mathematics performance. Paper presented at the National Association of Developmental Education,Cincinnati,OH. (ERIC Document Reproduction Service No: ED 304340).

Butterworth, B. (1999). The mathematical brain. London: Macmillan.

Fennema,E \& Sherman, J.A. (1976). Fennema- Sherman Mathematics Attitude Scales: Instruments designed to measure attitudes toward the learning of mathematics by females and males. Catalog of Selected Documents in Psychology, 6(2), 31.

Greenwood, J. (1984). My anxieties about math anxiety. Mathematics Teacher, 77, 662-663.
Hardfield, O.D., Martin, J.V., \& Wooden, S.(1992). Mathematics anxiety and learning style of Navajo Middle School student. School Science and Mathematics, 92(4),121-176.

Hembree, R. (1990). The nature, effects, and relief of mathematics anxiety. Journal for Research in Mathematics Education, 21, 33-46.

Jackson, C.D., \& Leffingwell, R. J. (1999) The role of instructors in creating math anxiety in students from kindergarten through college, Mathematics Teacher, 92(7), 583-586.

Jasmani Bidin, Noorzila, S. \& Kasim, Z. (2005). Kegelisaban matematik di kalangan pelajar menengah rendah di Perlis. Prosiding Simposium Kebangsaan Sains Matematik ke XIII.. [Mathematics anxiety among lower secondary school students in Perlis. Proceedings of the National Mathematical Science Simposium XIII].

Lazarus, M. (1974). Mathephobia: Some personal speculations. National Elementary Principal, 53, 16-22.

Levine, G. (1995). Closing the gender gap: Focus on mathematics anxiety. Contemporary Education ,67(1),42-45

$\mathrm{Ma}, \mathrm{X}$. (1999). A meta-analysis of the relationship between anxiety toward mathematics and achievement in mathematics. Journal for research in mathematics education, 30(5), 520-540.

Miller, L.D.,\& Mitchell, C.E. (1994). Mathematics anxiety and alternative methods of evaluation. Journal of Instructional Psychology, 21,353-358.

Norwood, K.S. (1994). The effects of instructional approach on mathematics anxiety and achievement. School Science and mathematics, 94, 248-254.

Quilter, D. \& Harper, E. (1988). Why we didn't like mathematics, and why we can't do it. Educational research, 30, 121-134.

Rahmah Murshidi (1999). Relationship between problem solving styles and mathematics anxiety among Form Four students. Master of Science Thesis, University Malaysia Sarawak.

Satake, E \& Amato, P. P. (1995). Mathematics anxiety and achievement among Japanese Elementary School Students. Educational and Psychological Measurement, 55, Issue 6.1000-1007.

Skiba, A.E. (1990). Reviewing an old subject: Math anxiety, Mathematics Teachers, 83: 188-189.

Stuart, V. (2000). Math curse or math anxiety? Teaching children mathematics, 6(5):330-35.

Tapia, M. (2004). The relationship of math anxiety and gender. Academic Exchange Quarterly, 8 (2).

Woodard, T. (2004). The Effects of Math Anxiety on PostSecondary Developmental Students as Related to Achievement, Gender, and Age, Inquiry, 9(1).

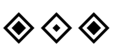

